Journal of Epidemiology and Public Health (2016), 1(2): 100-107

https://doi.org/10.26911/jepublichealth.2016.01.02.03

\title{
Multilevel Analysis on the Social Determinants of Cervical Cancer in Yogyakarta
}

\author{
Heni Elmiani Sari'), Ambar Mudigdo²), Argyo Dermatoto3) \\ ${ }^{1)}$ School of Midwifery (AKBID) Kutai Husada, Tenggarong, Indonesia \\ 2)Faculty of Medicine, Sebelas Maret University, Surakarta \\ 3)Faculty of Social and Communication, Sebelas Maret University, Surakarta
}

\begin{abstract}
Background: There are 527,600 new cases of invasive cervical cancer. Cervical cancer is caused by infection with the Human Papilloma Virus (HPV) 16 and 18 study was conducted in the city of Yogyakarta. This study aimed to analyze the social determinants on cervical cancer by multilevel analysis in Yogyakarta.

Subjects and Method: This was an observational analytic study with case control design. This was conducted on March 31 to May 4, 2016. A total of 120 samples were selected by fixed disease sampling with a ratio 1:3. The data collected was using a questionnaire and analyzed with Logistic Regression.

Results: The risk of cervical cancer with a positive effect on family income $(\mathrm{OR}=3.45 ; 95 \% \mathrm{CI}=$ 0.26 to $45.45 ; \mathrm{p}=0.346)$, age of first sexual intercourse $(\mathrm{OR}=8.54 ; 95 \% \mathrm{CI}=1.17$ to $62.41 ; \mathrm{p}=$ 0.034), number of sexual partners $(\mathrm{OR}=14.60 ; 95 \% \mathrm{CI}=2.93$ to $72.66 ; \mathrm{p}=0.001)$, oral contraceptives $(\mathrm{OR}=1.85 ; 95 \% \mathrm{CI}=0.37$ to $9.20 ; \mathrm{p}=0452)$, nutritional status $(\mathrm{OR}=5.69 ; 95 \% \mathrm{CI}=1.36$ to 23.82; $\mathrm{p}=0.017)$, hygiene genitalia $(\mathrm{OR}=9.23 ; 95 \% \mathrm{CI}=1.76$ to $48.35 ; \mathrm{p}=0.009)$, and an effect reversed by education $(\mathrm{OR}=0.14 ; 95 \% \mathrm{CI}=0.09$ to $2.08 ; \mathrm{p}=0.155)$. ICC value of $40.68 \%$ indicating the risk of cervical cancer in women varies and a variation of $40.68 \%$ at the level of environmental sanitation home.

Conclusion: There is a positive effect of family income, age of first sexual intercourse, number of sexual partners, nutritional status, hygiene genitalia, and sanitary home environment, on the risk of cervical cancer.There is an inverse effect of education on the risk of cervical cancer. The society is expected to be aware of cervical cancer.
\end{abstract}

Keywords: multilevel analysis, social determinants, cervical cancer.

\section{Correspondence:}

Heni Elmiani Sari. School of Midwifery (AKBID) Kutai Husada, Tenggarong, Indonesia. Email: henyelmiani@gmail.com

\section{BACKGROUND}

Cervical cancer is a type of cancer that is most often found in women in the world. Every year there are 527,600 new cases of invasive cervical cancer and 265,700 deaths worldwide in 2012 (Globocan, 2012). Cervical cancer in developed countries ranks fourth, while in developing countries, ranks first as a cause of death of women of reproductive age (Rasjidi, 2009). Almost all (99\%) of cervical cancer is caused by infection with the Human Papilloma Virus
(HPV), especially HPV 16 and 18 (Aziz et al., 2006).

Indonesia is the second country in the world after China which has the highest cervical cancer sufferers. Cervical cancer is the most types of cancer suffered by women in Indonesia,new cases of cervical cancer are found 40-45 cases per day, 52 million Indonesian women at risk for cervical cancer (Nurwijayaet al., 2010). Each year there are an estimated 190,000 new cases and fifth will die from cervical cancer 
(Diananda, 2007). Cervical cancer is the cancer with the highest prevalence in Indonesia in 2013, which amounted to $0.8 \%$ of cervical cancer. Province D.I. Yogyakarta has the highest prevalence of cervical cancer by $1.5 \%$ (Ministry of Health, 2015). According Riskesdas 2013, the incidence of cervical cancer in Yogyakarta reached 9.6 per 1,000 population. Cervical cancer is a disease that is not contagious, but causing a growing number of incidents leading to problems of economic, social and psychological because the expensive treatment affect especially the poor (PHO Yogyakarta, 2015).

Risk factors for cervical cancer occur in women include age marriage too early (less than 18 years) or starting sexual activity at a young age, women who smoke, the cleanliness of the genitalia are bad, the woman who gave birth to more than three times, women with sexual activity high and frequently changing partners and oral contraceptives. The high prevalence of cervical cancer resulted in an increased number of cervical cancer. Socioeconomic position, education and low income is one of the determinants that play a role in this condition (Melva, 2008).

According to Louie et al., (2009) women who are most at risk of cervical cancer are women who have a history of multiple sexual partners, sexual intercourse $<16$ years. In the study Rachmawati (2014) states that personal hygiene bururk can influence the occurrence of cervical cancer. Personal hygiene pads that do not include the use of quality and the use of antiseptics or vaginal cleaning. The use of oral contraceptives for 5-10 minutes has a four times higher risk of having cervical cancer compared with women who use oral contraceptives are less than 5 years (Vaisy et al., 2014). In the study Cooper et al., (2007) that satatus low socioeconomic usually increases sexual activity is high (having a limited income), access to health services is limited, poor nutrition and low levels of awareness about the problem of environmental sanitation and health maintenance and prevention behavior. According Hammouda et al., (2005) that indicators of poor environmental sanitation is the strongest factor for cervical carcinoma.

Based on data from the City Health Office Yogyakarta (2015) that cervical cancer is still high in Yogyakarta due to lack of knowledge about cervical cancer, unhealthy lifestyle, marry early age, women with multiple partners, a clean lifestyle and healthy, factors of environmental hygiene, as well as social environment which triggers activity and risky sexual behavior outside of marriage. Based on this background, the researchers are interested in knowing the social determinants of cervical cancer in the city of Yogyakarta.

\section{SUBJECTS AND METHOD}

This was an observational analytic study with case control design. A total sample was 120 subjects with 30 case group and 90 control group. The sample was selected using a Fixed Disease Sampling with a ratio 1:3. The independent variables were education, family income, age of first sexual intercourse, number of sexual partners, oral contraceptive, nutritional status, genitalia hygiene and environmental sanitation. The dependent variable was a cervical cancer. Data analysis was using multiple logistic regression analysis.

RESULTS
Characteristics of respondents were mater-
nal age, maternal education, and maternal
income. The subjects were categorized into
two groups; maternal age <40 years in case
group (30\%) and control (70\%), while those


Journal of Epidemiology and Public Health (2016), 1(2): 100-107

https://doi.org/10.26911/jepublichealth.2016.01.02.03

aged $\geq 40$ years in case group (23\%) and control (77\%). Mother's education categorized into 2 was $<12$ years (SMA) in case group (33\%) and control (67\%), while the $\geq$ 12 years of education (high school diploma, PT) in the case group (17.5\%) and controls (82.5\%). Jobs were classified in Yogyakarta, women who worked in the case group (10\%) and control (90\%) and who did not work in the case group (30\%) and control (70\%). The family income in the case group (39.6\%) was higher than the control group

Tabel 1. Result of Logistic Regression with a Multilevel Analysis of Social Determinant with Cervix Cancer

\begin{tabular}{|c|c|c|c|c|}
\hline \multirow{2}{*}{ Independent Variable } & \multirow{2}{*}{$\mathbf{O R}$} & \multicolumn{2}{|c|}{$95 \%$ CI } & \multirow{2}{*}{$\mathbf{p}$} \\
\hline & & Lower & Upper & \\
\hline \multicolumn{5}{|l|}{ Fixed Effect: } \\
\hline Maternal education $\geq 12$ years & 0.14 & 0.09 & 2.08 & 0.155 \\
\hline Family Income (Rp 1,452,400) & 3.45 & 0.26 & $45 \cdot 45$ & 0.346 \\
\hline Age of first sexual intercourse $<20$ years & 8.54 & 1.17 & 62.41 & 0.034 \\
\hline Number of sexual partners > 1 partner & 14.6 & 2.93 & 72.66 & 0.001 \\
\hline Oral Contraceptive $\geq 5$ tahun & 1.85 & 0.37 & 9.20 & 0.452 \\
\hline Nutritional status(BMI $<18.50$ or $\geq 23.00)$ & 5.69 & 1.36 & 23.82 & 0.017 \\
\hline Genitalia hygiene and environmental sanitation $<88$ & 9.23 & 1.76 & 48.35 & 0.009 \\
\hline \multicolumn{5}{|l|}{ Random Effect: } \\
\hline Constant & 0.00 & & & \\
\hline \multicolumn{5}{|l|}{ Environmental sanitation } \\
\hline Var (Constanta) & 2.25 & 0.40 & 12.71 & \\
\hline \multicolumn{5}{|l|}{ Kesesuaian model } \\
\hline Intraclass correlatio & $40.68 \%$ & & & \\
\hline Likelihood Ratio Test $\rho=$ & 0.0034 & & & \\
\hline
\end{tabular}

\section{DISCUSSION}

There were found influence (negative) between the mother's education and the risk of developing cervical cancer, but the effect was not statisticallysignificant. Mothers with higher education $\geq 12$ years are at risk for cervical cancer $1 / 9$ times lower than those with low education $<12$ years ( $\mathrm{OR}=0.14,95 \% \mathrm{CI}=0.09$ to $2.08, \mathrm{p}=0.155)$. Education affects someone in the decision to perform the early detection of cervical cancer (pap smear). Education also affect the cervical cancer risk, prevention and adherence to treatment elated to education, possibly mediated through a higher level (WHO, 2011).
(60.4\%). Family income lower case group (13.4\%) control (39.6\%) and control (86.6\%).

Effect of multivariate described the influence of the independent variables; maternal education, family income, age of first sexual intercourse, number of sexual partners, oral contraceptive, nutritional status, hygiene and environmental sanitation genitalia home. Data analysis used logistic regression with STATA 13.

According to research conducted to Franceschiet al., (2009) that educational level inversely with the risk of cervical cancer. Education level cannot be marked for a combination of characteristics that dominate in women with low education level. Dahlgreen and Whitehead (1991) says that the level of education is structural factors is influence health. because of the mother's education in Yogyakarta had the same educational background, so the mother with the positive or negative cervical cancer tend to have the same background.

The mother educational level can support a person's level of knowledge and low educational level which related to 
information and lack of knowledge. The higher educational level of information obtained and their knowledge would be even higher. Low educational causes a person does not care about the health existing program, so, they do not recognize the dangers that may occur.

The result showed that there was a positive influence between family income with cervical cancer risk $(\mathrm{OR}=3.45 ; 95 \%$ $\mathrm{CI}=0.26$ to $45.45 ; \mathrm{p}=0.157$ ). This is in line with research conducted by Mwaka et al., (2016) and Syatriani (2011) that cervical cancer is more common in low income community group that is 4 times more risk of developing cervical cancer than women with high income.

Factor income related to nutrition and immunity. Low income groups are usually generally had the quantity and quality of food that affects to body immunity. Low incomegroups are usually less accessible to good quality health services. It was including Pap smear in women aged 35 years and over. Low income women usually do not pay attention to the nutritional status and immunity. Family income can influence in the incidence of cervical cancer.

Age first sexual intercourse had a high risk for cervical cancer with the value $(\mathrm{OR}=$ 8.54; $95 \% \mathrm{CI}=1.17$ to $62.41 ; \mathrm{p}=0.034)$. There was a strong positive influence and statistical significance between ages of first sexual intercourse at risk for developing cervical cancer. Cooper et al., (2007) and Melva (2008) that women who had sexual intercourse were first <20 years likely to suffer cervical cancer. Based on the epidemiological studies cervical cancer increases ten times when sexual intercourse age less than 20 years.

According to Aziz (2006) married women under age less than 20 years, usually 10-12 times greater likelihood of cervical cancer than who were married or had sexual intercourse the first time more than 20 years which in the womb of a teenager is very sensitive. An adolescent cervical is more susceptible to carcinogenic stimulus because there is an active process of squamous metaplasia. Early commencement of sexual activity, particularly in adolescence associated with a greater risk of developing cervical cancer because of susceptibility to HPV infection (Ogunbode et al., 2005). Rodriguez (2012) stated culmination of transmission of HPV infection usually occurs early in the first year after the start of sexual intercourse, due to HPV infection is highly contagious and endemic. Women who had sex the first time aged $<17$ years 23 times the risk for cancer compared with those having sex aged $\geq 20$ years.

The number of couples more than one at risk for cervical cancer is 14 times graeter than the number of spouses only one (OR = 14.60; 95\% CI=2.93 to 72.66; $\mathrm{p}=0.001)$. Melva (2008) and Hamouda et al., (2005) that changing partners is a risk factor for cervical cancer. Dahlgren and Whitehead (1991) sated that the first layer (the microlevel, upstream/downstream) determinants of health include individual behavior and lifestyle which increases or detrimental to health.

Number of sexual partners is one of lifestyle factors to undergo cervical cancer. Women who have multiple sex partners are susceptible to HPV and cervical cancer. This is more exposed to various variants of the virus (Appleby et al., 2007).

According to the International Collaboration of Epidemiological Studies of Cervical Cancer (2006) has more than one sexual partner has more risk for cervical cancer. Development of cervical cancer is closely related to sexual behavior. Risk of cervical cancer will increase more than 10 times for women who have sexual partner more than one person. 
Journal of Epidemiology and Public Health (2016), 1(2): 100-107

https://doi.org/10.26911/jepublichealth.2016.01.02.03

Older oral contraceptive use are at risk for cancer $(\mathrm{OR}=1.85 ; 95 \% \mathrm{CI}=0.37$ to 9.20; $\mathrm{p}=0.452)$. There are between oral contraceptive use and risk of cervical cancer. The study conducted by Vaisy et al., (2014) and Roura et al., (2016) that the duration of oral contraceptive use have a risk three times more likely to have cervical cancer.

Long-term use of oal contraceptives can incease the risk of cervical cancer up to four times in women who are infected with HPV (Moreno et al., 2002 ; Naggar, 2014). Several studies from Maryland Medical Center (UMMC) University in 2015 shows that the hormones in oral contraceptives help the virus enter the genetic material of the cells of the uterus. Women who use oral contraceptives less to use a diaphragm, condoms, or other methods that can help at reducing the risk of transmission of HPV and other sexually transmitted diseases.

Women with normal nutritional status is not at risk for cervical cancer six times greater than women who do not with normal nutritional status ( $\mathrm{OR}=5.69 ; 95 \%$ $\mathrm{CI}=1.36$ to 23.82; $\mathrm{p}=0.017$ ). Poorolajal and Jenabi (2015) stated that overweight is not associated with an increased risk of cervical cancer, but the weak obesity associated to increase risk of cervical cancer. Based on Cohort study, to providing conclusive evidence of whether or not BMI associated with an increased risk of cervical cancer.

According to Al-Naggar, in his book Principles and Practice of Cancer Prevention and Control (2014) in patients with obese not only increases the risk of developing cancer, but their deaths also increased Body Mass Index (BMI). Obesity has been identified as a risk for some cancers, including endometrial cancer and cancer of breast, colon, rectum, esophagus, kidney, pancreas, gall bladder, ovary, cervix, and liver. Nutritional status is a state body that is the end result of a balance of nutrients that enter the body and its utilization (Sediaoetama, 2010).

Genitalia poor hygiene are at risk for cervical cancer than women with 9 times genitalia good hygiene $(\mathrm{OR}=9.23 ; 95 \% \mathrm{CI}=$ 1.76 to $48.35 ; \mathrm{p}=0.009$ ). Syatriani (2011) stated genitalia hygiene related to use of tight underwear, the use of pads and the use of vaginal cleansing soap. Women with vaginal infections, among other were using pads that are not qualified and habit in washing the vagina with an antiseptic as medicine washing and deodorants to maintain the cleanliness and health of the vaginal washing and deodorants to maintain the cleanliness and health of the vagina or other reasons can increase the risk of cancer. Genitalia poor hygiene led to the development of the fungus candida albicans. Candida itself is an infection cused by the fungus Candida species of microorganism.

Candida vaginal is disease that complexes, if it cannot maintain the cleanliness of vaginal then it is possible to be infected with the chronic candida. Candida albicans infection indicates a weakened immune system the body will lead to the growth of bacteria and cancer cells increases.

Sanitary home environment at level 2 ICC values are $40.68 \%$. The indicator shows that the risk of cervical cancer in women vary, as as $40.68 \%$ of the variation is determined at a high level, sanitary home environment.

This figure is greater than the value of $8-10 \%$ rule of thumb, then the house sanitation contextual influences shown from multilevel analysis is important. This study is in line with research conducted by Hammouda et al., (2005) that a bad environment or poor hygiene are at risk for cervical kaker 5 times bigger than a good environment. Environmental factors such 
as lifestyle, culture, diet, water and air quality plays a role in causing cancer in relation to the geographical area. The use of public toilets are also very influential on the development of HPV. Human Papilloma Virus may occur in environments that are not clean, so that the environment a great impact on human health due to various factors that cause the disease are influenced by the environment. Environmental sanitation is an important factor that must be considered especially clean water facilities (Kasnodiharjo, 2013).

Research conducted by $\mathrm{Li}$ et al., (2012) with multilevel analysis that environmental sanitation is less influence on morbidity and mortality of cervical cancer. Environmental sanitation is still lacking in the urban settlement is associated with poverty population, whereas in urban areas in developing countries characterized by crowding, congestion and density of settlements that affect air quality is not good. Poor environmental sanitation are usually widely available in commercial centers, such as market town, village outskirts and surrounding riparian State. The population density in this area tends to increase with different social background, economic and cultural, so the responsibility for the health of neighborhoods less attention. Environmental conditions are rundown houses and overpopulated environment around the health sanitary nor awake so cause someone to get sick

Environmental health problems are likely to have a direct effect on the health threatening. Housewives who had plenty of time to do the work in the home are more vulnerable to infection than men, because women bring a high level of responsibility for housework. Therefore, women have a major influence on the health of the home environment (Kjellen, 2001). House environmental sanitation in urban areas is connected with urbanization and population growth is an ongoing threat to the health (Pebley, 1998, in Kjellen, 2001).

According McGranahan et al., (1999) in Kjellen 2001 that almost half of the world's population live in urban areas about $2-3 \%$ of the land area on Earth, so it is important to address the sanitary quality of the home environment in urban areas. Lack of sanitation in urban areas is the use of public toilets are still in active use in urban areas, where women are also at increased risk for cervical cancer. the use of public toilets that have been exposed to the HPV virus, will transmit to another woman. Humid conditions toilet is a fertile place for the virus to multiply.

There are positive influence between income, age of first sexual intercourse, number of sexual partners, nutritional status, hygiene genitalia, and sanitary home environment on the risk of cervical cancer, and there is an inverse effect between education and the risk of cervical cancer.

\section{REFERENCE}

$\overline{\text { Al-Naggar (2014). Priciples and Practice of }}$ Cancer Prevention and Control. Cervical Cancer Prevention and Control. Omics e-book group.

Appleby P (2007). International Collaboration of Epidemiological Studies of Cervical Cancer and Hormonal Contraceptives: Collaborative Reanalysis of Individual Data for Women with Cervical Cancer 16.573 and 35.509 Women without Cervical Cancer from 24 Epidemiological Studies. Lancet. 10: 1609-1621.

Aziz MF (2006). Reference Books Gynecological Oncology. Jakarta: Yayasan Bina Library Sarwono Prawirohardjo.

City Health Office Survilan (2015). Integrated Data-Based Health Center of 
Journal of Epidemiology and Public Health (2016), 1(2): 100-107

https://doi.org/10.26911/jepublichealth.2016.01.02.03

Communicable Diseases. Yogyakarta: P2PL.

Cooper D Hoffman M, Carrara H, Rosenberg L, Kelly J, Stander I, Denny L, Williamson AL, Shapiro S (2007). Determinants of Sexual Activity and its Relation to Cervical Cancer Risk Among South African Women. Biomed central. 341 (7): 1-8.

Dahlgren G, Whitehead M (1991). Policies and Strategies to Promote Social Equity in Health. Stockholm: Institute fo Future Studies.

Diananda R (2007). Know the Inside Cancer. Yogyakarta: Kata Hati.

Franceshi S (2009). Differences in the Risk of Cervical Cancer and Human Papillomavirus Infection by Education Level. British journal of cancer. 101 (5): 865-870.

Globocan. Estimated (2012). Cancer Incidence, Mortality and Prevalence Worldwide. International Agency for Research on Cancer (IARC). WHO.

Hammmouda (2005). Cervical Carcinoma in Algiers, Algeria: Human Papillomavirus and Lifestyle Risk Factors. International journal cancer.113: 483489.

International Colaboration of Epidemiological Studies of Cervical Cancer (2006). Comparison of Risk Factors for Invasive Squamous Cell Carcinoma and Adenocarcinoma of the Cervix: Collaborative Reanalysis of Individual Data on 8097 Women with Squamous Cell Carcinoma and Adenocarcinoma with 1,374 Women from 12 Epidemiological Studies. International journal of cancer. 120: 885-891. Kasnodiharjo, Elsa E (2013). Description of Environmental Sanitation, Behavior, and Health. The national public health journals. 7 (9): 415-420.
Ministry of Health (2015). Basic Health Research, Research and Development Agency Ministry of Health and Population Data Targets. Pusdatin Ministry of Health.

Kjellen M (2001). Health and Environment. Democracy Department for Health and Social Development Division. Swedish International Development Cooperation Agency (SIDA).

Li X, Sundquist J, Calling S, Zoller B \& Sundquist K (2012). Neighborhood Deprivation and Risk of Cervical Cancer Morbidity and Mortality: A Multilevel Analysis From Sweden. Gynecology Oncology.127: 283-289.

Louie KS, sanjose SD, Diaz M, Castellsague $\mathrm{X}$, Herrero R, Meijer CJ, Shah K, Franceschi S, Munoz N, Bosch FX (2009). Early Age at First Sexual Intercourse and Early Pregnancy are Risk Factors for Cervical Cancer in Developing Countries. British journal of cancer.100: 1191-1197.

Melva (2008). Factors Affecting Cervical Cancer Incidence in Patients Treated Coming in Dr H. Adam Malik Medan. Medan: University of North Sumatera.

Moreno V, Bosch FX, Munoz N, Smith JS, Shah KV \& Sinjders P (2002). Effect of Oral Contraceptives on Risk of Cervical Cancer in Women with Human Papilloma Virus Infertion: The IARC Multicentric Case Control Study. Lancet. 359(9312): 1085-1092.

Murti B (1997). Principles and Methods of Research on the Epidemiology. Yogyakarta. Gadjah Mada University Press.

Mwaka AD, Garimoi CO, Were EM, Ronald M, Wabinga H, Lyratzopoulos. (2016). Social, Demographic, and Health care Factors Associated with Stage at Diagnosis Of Cervical Cancer: Cross Sec- 
tional in a Tertiary Hospital in Northern Uganda. BMJ. 1-10.

Nurwijaya H (2010). Prevention and Detection of Cervical Cancer. Jakarta: PT Elex Media Komputindo.

Ogunbode OO, Ayinde OA (2005). Awareness of Cervical Cancer and Screening in a Nigerian Female Population Market. Annals of African Medicine. 4 (4): 160-163.

Poorolajal L and Jenabi E (2015). The Association between BMI and Cervical Cancer Risk: a Meta-Analysis. European Journal of Cancer Prenvention. 1-7.

Rahmawati A (2012). Parity Relations with type Histopathology Cervix Uteri Carcinoma in Hospital Dr. Sardjito. Yogyakarta: Gadjah Mada University.

Rodriguez RP, Morelos PR, Ruiz VV, Rodriguez MM, Ponciano KT, Yebra BG, Rodriguez DM, Salcedo M (2012). Prevalence of Human Papillomavirus in the Cervical Epithelium of Mexican Women: Meta-Analysis. Indectious Agents and Cancer. 7 (34): 1-8.
Roura E (2016). The Influence of Hormonal Factors on the Risk of Developing Cervical Cancer and precancer: Results from the EPIC Cohort. Plosone. 11(1): 1-17.

Steffen A, Trichopoulou A, Sediaoetama (2010). Nutrition Science for Students and Professionals. Jakarta: Dian Rakyat.

Syatriani S (2011). Cervical Cancer Risk Factors at the Government General Hospital Dr. Wahidin Sudirohusodo Makassar, South Sulawesi. Journal of the national public health. 5(6): 283288.

University of Maryland Medical Center (2015). Cervical Cancer. Greene Street, Baltimore.

Vaisy A, Lotfinejad S, Zhian F (2014). Risk of Cancer with Combined Oral Contraceptive Use Among Iranian Women. Asian pacific journal of cancer prevention. 14 (15): 5517-5522.

World Health Organization (2011). Rio Political Declaration on Social Determinants of Health, Rio de Janeiro, Brazil 